e-makâlât Mezhep Araştırmaları, VII/1 (Bahar 2014), ss. 267-271.

ISSN 1309-5803 | www.emakalat.com

\title{
İSLAM TARİHİNDE NİFAK: ALİ
}

Kemaleddin Şükrü ORBAY, Necm-i İstikbal Matbaas1, İstanbul-1918, (176 Sayfa)

\section{Ali DURMUŞ ${ }^{1}$}

İslam Tarihinde, Hz. Osman'in halifeliği zamanında (h. 24-36), siyasî, ekonomik ve dinî bir takım problemlerin ortaya çıkmasıyla ilk defa halk ayaklanması vuku bulmuş, Hz. Osman kendi evinde canice katledilmişti. Bu olay ilk ihtilal, halifeye karşı başarılı olan ilk ayaklanma gibi bir takım ilkleri de bünyesinde barındırmaktadır. Çünkü ilk kez Müslüman olduğunu iddia eden bir grup tarafından Müslüman bir halife öldürülmüştü. $\mathrm{Hz}$. Osman'in öldürülmesi bu sorunların hiçbirine bir çözüm sunmamış, bilakis durumu daha da karmaşık ve halledilmesi imkânsız büyük bir siyasi-dinî mesele haline getirmiştir. Ayrıca bu durum bir domino etkisi yaratarak $\mathrm{Hz}$. Ali'nin halifelik makamına getirilişinden ölümüne kadar Cemel Vakası ve Siffìn Savaşı gibi birçok problemin başlangıç noktası olmuştur. İşte bütün bu ihtilaflar ve ihtilafların çıkış noktaları asırları delerek günümüze kadar problem olma özelliğini korumuş ve Mürciee, Şîâ, Havaric ve Ana Kitle/Ehl-i Sünnet’in doğuşunun temel sebebi haline gelmiştir.

Burada tanıtacağımız Kemaleddin Şükrü Orbay'ı İslam Tarihinde Nifak: Ali adlı eseri ${ }^{2} \mathrm{~Hz}$. Osman'a karşı girişilen isyandan $\mathrm{Hz}$.

\footnotetext{
1 İstanbul Üniversitesi Sosyal Bilimler Enstitüsü Temel İslam Bilimleri İslam Mezhepler Tarihi Anabilim Dalı Doktora Öğrencisi

2 Kemaleddin Şükrü Orbay, İslam Tarihinde Nifak: Ali, İstanbul, Necm-i İstikbal Matbaas1, 1918.
} 
Ali'nin öldürülmesine kadar geçen sürede yer alan bu denli önemli meseleleri ayrıntılı bir biçimde aktarmaktadır.

Orbay 1878 'de İstanbul'da doğmuştur. Mekteb-i Hukuk'u bitirdikten sonra Paris Sorbonne'de doktorasını yapmıştır. Eğitimini tamamladıktan sonra bir süre kaymakamlık görevinde bulunmuş sonra istifa ederek gazetecilik yapmaya başlamıştır. İlk olarak İzmir'de yayımlanan Yeni Asır gazetesinde yazı işleri müdürü olarak göreve başlayan Orbay, daha sonra değişik gazetelerde farklı görevlerde bulunmuştur. ${ }^{3}$ Tarih, Edebiyat ve İslam Dini alanlarında bir takım araştırmalarda ve incelemelerde bulunmuş ve birçok eser kaleme almıştır. Çalışmaları göz önünde bulundurulduğunda yazarın Alevi çevrelerden olma ihtimali yüksek olsa da elimizde bu bilgiyi kantllayabilecek ciddi bir delil bulunmamaktadır.

İslam Tarihinde Nifak: Ali adını taşıan bu eser, 1918'de Necm-i İstikbal Matbaasında eski harflerle neşredilmiş olup toplamda 176 sahifeden ibarettir ve tarafımızca latinize edilmiş ancak yayınlanmamıştır. Eserin ilk baskısının hangi yılda yapıldığ bilinmemektedir, ancak kaynaklarda zikredildiğine göre eser kaleme alındıktan sonra çok rağbet edilir hale gelmiş ve satış rekorları kırmıştır. ${ }^{4}$ Orbay'in eseri kaleme almasındaki temel amacı $\mathrm{Hz}$. Osman'in şehit edilmesinin $\mathrm{Hz}$. Ali dönemine nasıl etki ettiğini ve bu dönemde karş1laştığı problemlerin çözümünde Hz. Ali'nin nasıl bir yol takip ettiğini açıkça ortaya koyarak; Cemel vakasından Haricilerin zuhuruna kadar bir dizi olaylarda Hz. Ali'nin aslında haklı olduğunu ve tutarlı bir politika güttüğünü okuyucularına ispatlamaktır.

Eserde konusal başlıklandırma açısından sistematik bir diziliş bulunmamaktadır. Kendi başlıkları çerçevesinde izah edilecek olursa Hz. Osman'in öldürülmesinin anlatıldığı geniş bir mukaddime ile birlikte eser, Cemel Vakası, Siffin Vakası, Misir'in Muaviye Tarafindan Zabtı ve Şahadet Faciası olmak üzere beş ayrı bölüm ihtiva et-

3 Ömer Faruk Huyugüzel, İzmir Fikir ve Sanat Adamlarn (1850-1950), İzmir, Kültür Bakanlığı Yay. t.y., s. 301-302.

${ }^{4}$ Huyugüzel, a.g.e., s. 302. 
mektedir. Bölümlerin hacimleri arasında ciddi fark bulunmakta; bazı bölümlere daha detaylı bir şekilde yer verilirken bazı bölümlerin zayıf bırakıldığı görülmektedir. Bu itibarla eserin tasnifinde akademik bir kaygının olmadığı anlaşılmaktadır.

Yazar yaklaşık 60 sayfalık mukaddimesinde, Hz. Osman'ın asiler tarafından şehit edilişini, halifelik için yapılan görüşmeleri ve Ali b. Ebî Talib'e biatın nasıl gerçekleştiğini, ardından ise Osman b. Affan'ın ölümüyle asilerin hızlandırdığı nifak hareketlerini ayrıntılı bir şekilde aktarmaktadır (s. 3-63). "Cemel Vakası" başlıklı birinci bölümde ise Cemel olayına neden olan sebepleri, Hz. Aişe, Talha b. Ubeydullah ve Zübeyr b. Avvâm'nn bir araya gelişini, Cemel Vakas1nın seyrini, savaş meydanında tarafeyn arasında geçen diyalogları geniş bir perspektifte ele almıştır (s. 64-100). Ayrıca yazar bu bölümde Amr b. el-As, Muaviye b. Ebî Süfyân ve Ali b. Ebî Talib arasındaki ilişkiyi tarihi rivayetler çerçevesinde ele almıştır (s. 100-124) "Siffin Vakası" adlı ikinci bölümde yazar, Ali b. Ebî Talib ile MuaviyeAmr b. As üçlüsü arasında cereyan eden olayların Siffìn savaşını nasıl etkilediğini, savaşın nasıl gerçekleştiğini, savaş esnasındaki görüşmeleri, çarpışmaların nasıl vuku bulduğunu, hakem olayını, hakemlerin nihai kararını, Haricilerin doğuşuna neden olan sebepleri ve Hariciliğin doğuşunu ele almaktadır (s. 125-168). "Misır'ın Muaviye Tarafindan Zabtı" adlı üçüncü bölümde ise Muaviye b. Ebî Süfyân'in Amr b. el-Ass komutasındaki bir ordu ile Misır'ı ele geçirişini nakletmektedir (s. 169-170). "Şahadet Faciası" adlı son bölümde ise Haricilerin Hz. Ali, Muaviye ve Amr b. el-As'a suikast düzenlemelerini ve bu sebeple Hz. Ali'nin şehit oluşunu aktarmaktadır (s. 171- 176).

Yazar konuyu işlerken herhangi bir çelişki içerisine düşmemiştir. Ancak Hz. Ali dönemindeki bazı politik-dinî problemleri tamamen Hz. Ali lehine yorumlamış ve her meseledeki görüşünü naklederek, fikirlerinde onun her zaman isabetli olduğunu vurgulamıştır. Olayların sebepleri ve sonuçları üzerinden bazı mantıksal analizler yaparak görüşlerini temellendirmiştir. Buna mukabil Talha b. Ubeydullah, Zübeyr b. Avvam, Amr b. el-Âs, Muaviye b. Ebî Süfyan ve Hariciler aleyhine kullandığı uç ifadeler oldukça dikkat çekicidir. 
Örneğin; Hz. Ali'nin imamete getirilmesi konusunu ele alırken, Talha ve Zübeyr’i imamet makamında gözü bulunan ancak haricilerden korktukları için imameti kabul etmeyen, makam-mansıp sevdası gözlerini bürümüş, hırslı ve uyanık birer kişi olarak tarif etmektedir (s. 57, 61). Yine Amr b. el-Âss'a ve Muaviye'ye karşı, içleri şeytanî fikirlerle dolu, melun, müfsit, dessas, haris, halkı dalalete götüren birer bozguncu v.b. hakaretamiz ifadeler kullanmaktadır (s. $81,101,103,109)$. Yazarın bu ifadeleri eserinin başında uyacağına dair söz verdiği "tarafsızlık” ilkesine sadık kalmadığının açık delilidir.

Orbay, eserinde tarihsel-betimleyici ve öyküleyici bir üslup kullanmış, bu üslubu eserin akıcılığını artırmış ancak bilimselliğine gölge düşürmüştür. Olayları naklederken oldukça ayrıntılara inmiş ve kişiler arasındaki diyalogları dahi öyküleyici bir üslupla nakletmiştir. Bu durum eseri bilimsel bir metinden öte edebi bir sanat eserine dönüştürmüştür.

Kaynaklar açısından değerlendirildiğinde Orbay mukaddimesinde eseri kaleme alırken güvenilir İslam Tarihi kaynaklarından istifade ettiğini ileri sürse de bunlardan sadece iki tanesine değinmiştir. Bunlardan biri Cemaleddin Ataullah Hüseynî'nin Ravzâtü'lAhbâb adlı eseri (s. 43) diğeri ise İbnü'l-Esîr'in Tarih'idir (s. 107). Zikrettiği bu kaynakların ise İslam Tarihinin ikinci el kaynaklarından olması, birincil kaynaklardan yararlanılmadığının, ya da yararlanılsa da bunların belirtilmediğinin göstergesidir. Öte yandan yazar özellikle Cemel ve Sıffìn savaşı gibi olayları ele alırken kullandığı cümleler ve ifadeler ile İbnü'l-Esîr'in el-Kamil fi't-Tarih ve İbn Kesîr'in el-Bidâye'sindeki ilgili kısımlarla basit bir şekilde mukayese edildiğinde hemen hemen aynı cümlelerin bu eserlerde mevcut olduğu görülmektedir. Bu durum yazarın ilgili konuların anlatımında bu ve benzeri eserlerden açıkça faydalandığını ancak kaynaklara çoğunlukla atıfta bulunmadığının göstergesidir.

Alanındaki diğer eserlerle kıyaslanınca çalışma, İslam Tarihi klasiklerinde konuyla ilgili geçen bilgilerin tekrarı niteliğinde olmasına rağmen Osmanlı'nın son dönem araştırmacılarından biri olan Orbay'ın 20. yy.'ın başlarında kendi fikirlerini açıkça yansıtması hase- 
biyle alanında özgün bir çalışma olarak addedilebilir. Bu eser 1900'lü yıllarda kaleme alınmış bir eserdir, bu sebeple hem biçim hem de içerik açısından modern dönemdeki çalışmalardan farklılık göstermektedir. Eserin yazılmasında, akademik kaygılardan ziyade Hz. Ali tasavvurunun oluşmasında, onun haklılığını göstermeye yönelik halka dönük bir yayın olduğu düşünülebilir. 
